Vol. 4, No. 2, Nopember 2018

p-ISSN: 2442-8884 / e-ISSN: 2541-4542

J-Kesmas

Jurnal Kesehatan Masyarakat

\title{
HUBUNGAN STATUS GIZI DENGAN PRESTASI BELAJAR PADA SISWA DI SMK NEGERI 1 POLEWALI KECAMATAN POLEWALI KABUPATEN POLEWALI MANDAR
}

\author{
Nursiah Yaco', Urwatil Wusqa Abidin ${ }^{2}$ \\ Fakultas Kesehatan, Universitas Al Asyariah Mandar \\ E-mail : nursiahyaco@gmail.com
}

\begin{abstract}
ABSTRAK
Gizi merupakan salah satu faktor penentu utama kualitas Sumber Daya Manusia. Status gizi yang baik akan mempengaruhi proses pertumbuhan dari perkembangan anak, salah satunya dapat meningkatkan kemampuan intelektual yang akan berdampak pada prestasi belajar di sekolah. Tujuan penelitian ini adalah untuk mengetahui hubungan status gizi dengan prestasi belajar pada remaja siswa di Sekolah Menengah KejuruanNegeri 1 Polewali Kecamatan Polewali Kabupaten Polewali Mandar. Jenis penelitian yang digunakan adalah penelitian kuantitatif dengan menggunakan desain penelitian cross sectional. Pengambilan sampel dilakukan dengan mengunakan teknik Simple random sampling dengan jumlah sampel sebanyak 77 siswa. Variabel dalam penelitian ini adalah status gizi siswa terhadap prestasi belajar. Pengumpulan data dilakukan dengan pengambilan data primer dan data sekunder. Analisis data dilakukan dengan analisis univariat dan bivariat dengan menggunakan uji chi-square. Hasil penelitian ini menunjukkan terdapat hubungan status gizi dengan prestasi belajar pada remaja siswa di Sekolah Menengah Kejuruan Negeri 1 Polewali Kecamatan Polewali Kabupaten Polewali Mandar dengan nilai $p$ value $=0,025$.
\end{abstract}

Kata kunci : Status Gizi, Prestasi Belajar

\section{PENDAHULUAN}

Indonesia sehat 2010 merupakan

salah satu agenda keberhasilan

pembangunan nasional dalam rangka

mewujudkan kualitas sumber daya

manusia yang sehat, cerdas, produktif

dan mandiri. Meningkatkan suatu gizi

penduduk merupakan suatu dasar gizi

untuk membangun sumber daya yang

berkualitas dimulai sedini mungkin. ${ }^{1}$

Masalah gizi dikenal sebagai

masalah yang multikompleks karena disamping banyaknya faktor satu dengan faktor lainnya. Masalah gizi kurang masih tersebar luas di Negara berkembang, termasuk Indonesia. Pada saat ini masalah gizi lebih adalah masalah gizi di Negara maju, yang juga mulai terlihat di Negara berkembang termasuk Indonesia sebagai dampak keberhasilan di bidang ekonomi.

Salah satu indikator keberhasilan yang dapat dipakai untuk mengukur keberhasilan suatu bangsa 
Vol. 4, No. 2, Nopember 2018

J-Kesmas

Jurnal Kesehatan Masyarakat

dalam membangun sumber daya manusia adalah indeks Pembangunan Manusia (IPM) atau Human Development Index. Berdasarkan IPM maka pembangunan sumber daya manusia Indonesia belum menunjukkan hasil yang menggembirakan. Pada tahun2007, IPM Indonesia menempati peringkat 111 dari 182 negara, yang merupakan peringkat lebih rendah dibandingkan peringkat IPM negaranegara tetangga. Rendahnya IPM ini dipengaruhi oleh rendahnya status gizi dan kesehatan penduduk. IPM Sumatera Barat tahun 2008 adalah 72,96 berada rangking 9 secara nasional, sedangkan kota Padang adalah 77,20 berada pada rangking 16.

Secara umum prestasi belajar siswa di Indonesia ditentukan oleh kemampuan kognitifnya dalam memahami sebaran materi pelajaran yang telah ditentukan didalam kurikulum, contoh konkritnya adalah dalam penyelenggaraan ujian nasional (UN). Dalam dua tahun terakhir ini terjadi penurunan tingkat kelulusan pada tingkat SMA dan MA baik pada tingkat nasional yaitu dari $93,4 \%$ pada tahun 2009 menjadi $89,88 \%$ pada tahun 2010 dengan total peserta yang mengikuti UN SMA dan MA sebanyak
p-ISSN: 2442-8884 / e-ISSN: 2541-4542

1.522.162 orang dengan siswa yang tidak lulus 154.079 atau $10,12 \%$ maupun pada tingkat provinsi Sulawesi Barat yaitu dari tahun 2009 angka kelulusan siswa SMA dan MA di Sulbar mencapai 88,56 persen. Sedangkan tahun ini tingkat kelulusan hanya 79,87 persen (Berita kota Makassar,2010).

Hasil survei tahun 2007, nilai rata-rata prestasi siswa sebesar 397,1 dan sebesar 427,0. Nilai rata-rata sebesar ini menempatkan Indonesia pada posisi 35 dan 49 negara peserta. Rangking ini tidak jauh berbeda dengan hasil survei tahun 2003 maupun tahun 1999. Jika dibandingkan dengan prestasi siswa dari negara-negara Asia Tenggara lainnya, prestasi siswa Indonesia masih dibawah Philipina. Oleh karena itu perlu ada upaya perbaikan dalam pembelajaran sehingga prestasi siswa Indonesia dapat ditingkatkan. $^{4}$

Prestasi belajar siswa bukan semata-mata karena kecerdasan siswa saja tetapi ada faktor lain yang dapat mempengaruhi prestasi belajar tersebut.Faktor-faktor yang mempengaruhi prestasi belajar siswa adalah faktor internal yang meliputi faktor fisiologis dan psikologis, dimana status gizi termasuk faktor fisiologis 
Vol. 4, No. 2, Nopember 2018

p-ISSN: 2442-8884 / e-ISSN: 2541-4542

J-Kesmas

Jurnal Kesehatan Masyarakat

tersebut, faktor eksternal, dan faktor pendekatan belajar.

Masalah gizi remaja perlu mendapatkan perhatian khusus karena pengaruhnya yang sangat besar terhadap pertumbuhan dan perkembangantubuh serta dampaknya pada masalah gizi saat dewasa. Anak usia 11 sampai 18 berada pada masa puber yaitu sedang dalam masa peralihan ke remaja.

Menurut Riset Kesehatan Dasar 2013, prevalensi kurus pada remaja umur 16-18 tahun secara nasional sebesar 9,4 persen (1,9\% sangat kurus dan $7,5 \%$ kurus) dan prevalensi gemuk pada remaja umur 16-18 tahun sebanyak 7,3 persen yang terdiri dari 5,7 persen gemuk dan 1,6 persen obesitas. Provinsi dengan prevalensi gemuk tertinggi adalah DKI Jakarta $(4,2 \%)$ dan terendah adalah Sulawesi Barat $(0,6 \%) .{ }^{\mathrm{i}}$

Rendahnya status gizi anak akan membawa dampak negatif pada peningkatan kualitas sumber daya manusia. Belum sepenuhnya konklusif, namun diyakini bahwa kurang gizi kronis berhubungan erat dengan pencapaian akademik murid sekolah yang semakin rendah.Anak-anak yang stunting (pendek) karena kurang gizi ternyata lebih banyak yang terlambat 
Vol. 4, No. 2, Nopember 2018

p-ISSN: 2442-8884 / e-ISSN: 2541-4542

J-Kesmas

Jurnal Kesehatan Masyarakat

Square dengan tingkat kemaknaan $\alpha=$ $5 \%$.

HASIL

\section{Karakteristik Umum Responden}

Hasil analisis karakteristik responden menurut jenis kelamin lakilaki sebanyak 28 siswa $(36,36 \%)$ dan perempuan 49 siswa (63.64\%).

Sedangkan proporsi umur responden yang paling banyak yaitu umur 17 tahun yaitu 51 siswa $(66,23 \%)$ sedangkan umur yang paling sedikit yaitu umur 16 tahun yaitu 2 siswa (2,60\%). Proporsi tingkat pendidikan ayah responden terbanyak adalah SMP yaitu 26 orang $(33,77 \%)$ sedangkan yang paling sedikit yaitu D2 dan D3 yaitu 1 orang (1,30\%). Proporsi jenis pekerjaan didapatkan bahwa jenis pekerjaan ayah responden yang paling banyak adalah profesi wiraswasta yaitu 56 orang $(72,72 \%)$ sedangkan yang paling sedikit yaitu pegawai negeri yaitu 2 orang $(2,60 \%)$. Proporsi tingkat pendidikan ibu responden terbanyak adalah SMP yaitu 28 orang $(36,36 \%)$ sedangkan yang paling sedikit yaitu S3 dan D1 yaitu 1 orang $(1,30 \%)$. Proporsi jenis pekerjaan didapatkan bahwa jenis pekerjaan ibu responden yang paling banyak adalah profesi ibu rumah tangga yaitu 64 orang

$(83,12 \%)$ sedangkan yang paling sedikit yaitu guru dan pegawai swasta yaitu 1 orang $(1,30 \%)$.

\section{Variabel yang di Teliti}

Tabel 1 Distribusi Responden Berdasarkan Status Gizi Siswa

\begin{tabular}{ccc}
\hline Status Gizi & Frekuensi & $\mathbf{( \% )}$ \\
\hline Baik & 50 & 64.9 \\
Lebih & 21 & 27.3 \\
Kurang & 6 & 7.8 \\
\hline Jumlah & $\mathbf{7 7}$ & 100 \\
\hline
\end{tabular}

Berdasarkan pengukuran terhadap status gizi siswa berdasarkan indeks $\mathrm{BB} / \mathrm{TB}$ menurut umur, didapatkan siswa dengan status gizi baik sebanyak 50 siswa (64.9\%), status gizi lebih sebanyak 21 siswa (27.3\%) sementara siswa dengan status gizi kurang sebanyak 6 siswa (7.8\%).

Tabel 2 Distribusi Responden Berdasarkan Prestasi Belajar Siswa

\begin{tabular}{ccc}
\hline $\begin{array}{c}\text { Prestasi } \\
\text { Belajar }\end{array}$ & Frekuensi & $\begin{array}{c}\text { Persentase } \\
\text { (\%) }\end{array}$ \\
\hline Baik & 57 & 74.0 \\
Cukup & 19 & 24.7 \\
Kurang & 1 & 1.3 \\
\hline Jumlah & 77 & 100 \\
\hline \multicolumn{2}{c}{ Berdasarkan } & pengukuran \\
terhadap prestasi belajar dengan nilai
\end{tabular}


Vol. 4, No. 2, Nopember 2018

p-ISSN: 2442-8884 / e-ISSN: 2541-4542

$\mathrm{J}$-Kesmas

Jurnal Kesehatan Masyarakat

rapor didapatkan siswa dengan prestasi

belajar baik sebanyak 57 siswa (74.0\%),

prestasi belajar cukup sebanyak 19 siswa $(24.7 \%)$ dan prestasi belajar kurang sebanyak 1 siswa (1.3\%).

\section{Uji Statistik}

\section{Hubungan status gizi dengan prestasi}

belajar siswa

Tabel 3 Analisis Hubungan Status Gizi

Dengan Prestasi Belajar Siswa

\begin{tabular}{|c|c|c|c|c|c|c|c|}
\hline \multirow{3}{*}{ Status Gizi } & \multicolumn{4}{|c|}{ PrestasiBelajar } & \multirow{2}{*}{\multicolumn{2}{|c|}{ Jumlah }} & \multirow{3}{*}{$\begin{array}{c}p \\
\text { value }\end{array}$} \\
\hline & \multicolumn{2}{|c|}{ Baik } & \multicolumn{2}{|c|}{ Kurang } & & & \\
\hline & $\mathbf{n}$ & $\%$ & $\mathbf{n}$ & $\%$ & $\mathbf{N}$ & $\%$ & \\
\hline Baik & 41 & 53.2 & 9 & 11.7 & 50 & 64.9 & \\
\hline Lebih & 14 & 18.2 & 7 & 9.1 & 21 & 27.3 & 0.025 \\
\hline Kurang & 2 & 2.6 & 4 & 5.2 & 6 & 7.8 & \\
\hline Jumlah & 57 & 74.0 & 20 & 26.0 & 77 & 100 & \\
\hline
\end{tabular}

Dari tabel 3 diatas dapat diketahui bahwa siswa yang berstatus gizi baik dengan prestasi belajar baik sebanyak 41 siswa (53.2\%) dan siswa yang berstatus gizi baik dengan prestasi belajar kurang sebanyak 9 siswa $(11.7 \%)$. Siswa yang berstatus gizi lebih dengan prestasi belajar baik sebanyak 14 siswa (18.2\%) dan siswa yang berstatus gizi lebih dengan prestasi belajar kurang sebanyak 7 siswa (9.1\%). Sedangkan yang berstatus gizi kurang dengan prestasi

belajar baik sebanyak 2 siswa (2.6\%) dan siswa yang berstatus kurang baik dengan prestasi belajar kurang sebanyak 4 siswa (5.2\%).

Berdasarkan hasil uji statistik didapatkan hasil bahwa ada hubungan antara status gizi dengan prestasi belajar siswa di Sekolah Menengah Kejuruan Negeri 1 Polewali dengan nilai $p$ value $=0.025<$ pvalue $=0,05$.

\section{PEMBAHASAN}

SMK Negeri 1 Polewali Mandar, berada pada posisi yang sangat strategis karena selain sangat mudah untuk dijangkau, juga sangat berdekat dengan pusat perbelanjaan, tempat wisata, rumah sakit dan kantor polisi. SMK Negeri 1 Polewali Mandar, memiliki luas tanah $14.080 \mathrm{~m}^{2}$.

Berdasarkan hasil penelitian menunjukkan bahwa sebagian besar siswa berstatus gizi baik, yaitu sebanyak 50 siswa (64,9\%) dengan indikator $\mathrm{BB} / \mathrm{TBB}$ menurut umur. Hanya sebagian kecil siswa dengan status gizi tidak baik yaitu, gizi lebih sebanyak 21 siswa $(27,3 \%)$ dan gizi kurang sebanyak 6 siswa atau $(7,8 \%)$. Data penelitian menunjukkan bahwa siswa dengan status gizi baik, lebih dan 
Vol. 4, No. 2, Nopember 2018

p-ISSN: 2442-8884 / e-ISSN: 2541-4542

$\mathrm{J}$-Kesmas

Jurnal Kesehatan Masyarakat

kurang, lebih banyak ditemukan siswa

prestasi belajar siswa di Sekolah dengan status gizi baik daripada siswa Menengah Kejuruan Negeri 1 Polewali. dengan status gizi lebih dan kurang. Hasil uji statistik didapatkan nilai pada Berdasarkan data tersebut, hanya uji analisis dengan chi square sebagian kecil siswa sekolah menengah kejuruan negeri 1 polewali kecamatan polewali yang berstatus gizi tidak baik.

Hasil penelitian pada sampel yang berjumlah 77 siswa dapat dikatakan bahwa 57 orang siswa $(74,0 \%)$ siswa memiliki prestasi baik, 19 orang siswa $(24,7 \%)$ siswa dengan prestasi cukup dan 1 orang siswa $(1,3 \%)$ dengan prestasi kurang.

Menurut data nilai yang peneliti kumpulkan dari sekolah, nilai untuk siswa dengan prestasi belajar baik berada pada rentangan 80-90. Sedangkan untuk prestasi belajar kurang baik berada pada rentangan 70 79. Berdasarkan dari data tersebut didapatkan bahwa prestasi belajar siswa Sekolah Menengah Kejuruan negeri 1 Polewali Kecamatan Polewali rata-rata baik dikarenakan lebih banyak ditemukan siswa dengan prestasi belajar baik daripada prestasi belajar kurang.

Berdasarkan hasil penelitian yang telah dilakukan terdapat adanya hubungan antara status gizi dengan 
Vol. 4, No. 2, Nopember 2018

J-Kesmas

Jurnal Kesehatan Masyarakat

Hasil penelitian ini sama dengan penelitian yang dilakukan oleh Nuri Muliani 2009 didapatkan bahwa sebagian besar siswa Sekolah Dasar Negeri Buyut Udik sebanyak 69,33\% mempunyai status gizi baik serta prestasi belajar siswa sebagian besar $49,33 \%$ adalah baik. Terdapat hubungan yang bermakna antara status gizi dengan prestasi belajar siswa.

Hasil penelitian ini juga sama dengan penelitian yang dilakukan oleh Rosita Hayatus Sa'adah dkk didapatkan siswa Sekolah Dasar Negeri 01 Guguk Malintang mengalami stunting dan wasting, yaitu $7,5 \%$ dan $21,66 \%$. Prestasi belajar siswa Sekolah Dasar Negeri 01 Guguk Malintang Kota Padang Panjang dibawah rata-rata sebesar 30,8\%. Terdapat hubungan yang bermakna antara status gizi stunting dan status gizi wasting dengan prestasi belajar siswa.

Hal ini disebabkan karena siswa yang mempunyai status gizi baik dengan prestasi belajar baik lebih banyak dibandingkan dengan anak yang mempunyai status gizi tidak baik. Ketidakseimbangan antara asupan kebutuhan atau kecukupan akan menimbulkan masalah gizi, baik itu
p-ISSN: 2442-8884 / e-ISSN: 2541-4542

berupa masalah gizi lebih maupun gizi kurang. Masalah gizi kurang pada remaja akan berdampak negatif pada tingkat kesehatan masyarakat, misalnya penurunan prestasi belajar dan penurunan kesegaran jasmani.

Berdasarkan hasil yang didapat didukung dengan mengutip pendapat (Anwar, 2008) dalam legi, 2012 bahwa pengaruh makanan terhadap perkembangan otak, apabila makanan tidak cukup mengandung zat-zat gizi yang dibutuhkan dan keadaan ini berlangsung lama akan menyebabkan perubahan metabolisme dalam otak, berakibat terjadi ketidak mampuan berfungsi normal. Kenyataan tersebut menunjukkan bahwa aspek gizi dan pemenuhannya merupakan hal penting dalam pertumbuhan anak terutama anak usia sekolah dalam menigkatkan perkembangan intelektual guna meningkatkan prestasi pembelajarnnya.

Dalam hal ini sesuai teori yang diungkap dalam Ristiyati 2014 bahwa kelompok anak remaja umur 16-18 tahun kelompok yang rentan terhadap gizi karena anak remaja lebih suka makan-makanan jajanan yang kurang bergizi seperti goreng-gorengan, coklat, permen dan es. Sehingga makanan yang 
Vol. 4, No. 2, Nopember 2018

p-ISSN: 2442-8884 / e-ISSN: 2541-4542

$\mathrm{J}$-Kesmas

Jurnal Kesehatan Masyarakat

beraneka ragam tidak dikonsumsi atau tidak seimbang dengan kalori yang diperlukan.

Status gizi adalah keadaan tubuh sebagai akibat konsumsi makanan dan penggunaan zat-zat gizi (Almatsier, 2010). Faktor-faktor yang mempengaruhi status gizi antara lain pola konsumsi makan, tingkat pendapatan, faktor sosial budaya, pengetahuan gizi dan penyakit infeksi. Dalam penelitian ini status gizi diperoleh dengan pengukuran anthropometri yaitu berat badan dan tinggi badan yang dinyatakan dalam Indeks Massa Tubuh (IMT), yang merupakan salah satu perwujudan dari status kesehatan seseorang.

Rendahnya status gizi jelas berdampak pada kualitas sumber daya manusia. Oleh karena status gizi merupakan faktor yang memberikan pengaruh cukup besar terhadap prestasi seseorang. Gizi merupakan salah satu faktor penting dalam memberikan kontribusi terhadap kualitas sumber daya manusia.

Dimana pengaruh makanan terhadap perkembangan otak, apabila makanan tidak cukup mengandung zat-

zat gizi yang dibutuhkan, dan keadaan ini berlangsung lama, akan menyebabkan perubahan metabolisme dalam otak, berakibat terjadi ketidakmampuan berfungsi normal.

Pada keadaan yang lebih berat dan kronis, kekurangan gizi menyebabkan pertumbuhan badan terganggu, badan lebih kecil diikuti dengan ukuran otak yang juga kecil. Jumlah sel dalam otak berkurang dan terjadi ketidakmatangan dan ketidaksempurnaan organisasi biokimia dalam otak.

Keadaan ini berpengaruh terhadap perkembangan kecerdasan anak (Anwar, 2008). Kekurangan atau kelebihan zat-zat esensi gizi bisa mempengaruhi terjadinya learning disabilities (gangguan belajar), bekerja kurang, kesakitan sampai kematian. Masalah-masalah gizi yang terjadi di Indonesia masih sangat banyak antara lain Kekurangan Energi Protein (KEP), Anemia, KurangVitamin A (KVA), Gangguan Akibat Kekurangan Yodium (GAKY) yang sangat mempengaruhi konsentrasi dan kemampuan belajar siswa. 
Vol. 4, No. 2, Nopember 2018

p-ISSN: 2442-8884 / e-ISSN: 2541-4542

$\mathrm{J}$-Kesmas

Jurnal Kesehatan Masyarakat

Asupan gizi yang baik berperan penting dalam mencapai pertumbuhan badan yang optimal. Pertumbuhan badan yang optimal ini mencakup pertumbuhan otak yang sangat menentukan kecerdasan seseorang. Dampak akhir dari konsumsi gizi yang baik dan seimbang adalah meningkatnya kualitas sumber daya manusia.

Selain itu faktor lingkungan keluarga juga dapat mempengaruhi prestasi belajar siswa, faktor lingkungan keluarga ini meliputi faktor orang tua, suasana rumah dan keadaan ekonomi keluarga, tetapi dalam hal ini faktor tersebut tidak diteliti. Faktor orang tua menurut Abu Ahmadi (2007) faktor orang tua merupakan faktor yang besar pengaruhnya terhadap keberhasilan anak dalam belajar. Tinggi rendahnya pendidikan orang tua, besar kecilnya penghasilan, cukup atau kurang perhatian dan bimbingan orang tua, rukun atau tidaknya kedua orang tua, akrab atau tidaknya hubungan orang tua dengan anak-anak. Tenang atau tidaknya situasi dalam rumah, semuanya itu turut mempengaruhi pencapaian hasil belajar anak. Orang tua yang dapat mendidik anak-anaknya dengan cara memberikan pendidikan yang baik tentuakan sukses dalam belajarnya. Sebaliknya orang tua yang tidak mengindahkan pendidikan anakanaknya, acuh tak acuh, bahkan tidak memperhatikan sama sekali tentu tidak akan berhasil dalam belajarnya.

Kemudian faktor suasana rumah, besar kecilnya rumah tempat tinggal, ada atau tidaknya peralatan atau media belajar seperti papan tulis, gambar, peta, ada atau tidaknya kamar atau meja belajar dan sebagainya. Semuanya itu juga turut menentukan keberhasilan belajar seseorang.

Kemudian faktor ekonomi keluarga menurut Abu Ahmadi (2007) banyak menentukan juga dalam belajar anak. Kalau ekonomi keluarga kurang, kebutuhan hidup dan perlengkapan belajar belum dapat dipenuhi dengan baik. Sebaliknya, bila ekonomi keluarga sudah baik, kebutuhan hidup dan belajar dapat dipenuhi. Misalnya anak dari keluarga mampu dapat membeli alatalat sekolah dengan lengkap, sebaliknya anak-anak dari keluarga miskin tidak dapat membeli alat-alat itu. Dengan alat yang serba tidak lengkap inilah maka hati anak-anak menjadi kecewa, mundur, putus asa sehingga dorongan 
Vol. 4, No. 2, Nopember 2018

J-Kesmas

Jurnal Kesehatan Masyarakat

belajar menjadi kurang sekali, sehingga kecenderungan bermain dan santai meningkat.

Selain itu keadaan sekolah tempat belajar turut mempengaruhi tingkat keberhasilan belajar. Kualitas guru, metode mengajarnya, kesesuaian kurikulum dengan kemampuan anak, keadaan fasilitas atau perlengkapan di sekolah, keadaan ruangan, jumlah murid per kelas, pelaksanaan tata tertib sekolah dan sebagainya, semua ini turut mempengaruhi keberhasilan belajar anak. Bila suatu sekolah kurang memperhatikan tata tertib (disiplin), maka murid-muridnya kurang mematuhi perintah para guru dan akibatnya mereka tidak mau belajar sungguh-sungguh di sekolah maupun dirumah. Hal ini mengakibatkan prestasi belajar anak menjadi rendah. Demikian pula jika jumlah murid perkelas terlalu banyak (50-60 orang), dapat mengakibatkan kelas kurang tenang, murid menjadi kurang acuh terhadap gurunya, sehingga motivasi belajar menjadi lemah. ${ }^{11}$

\section{KESIMPULAN}

Sebagian besar siswa berstatus gizi baik yaitu sebanyak 50 siswa
p-ISSN: 2442-8884 / e-ISSN: 2541-4542

(64.9\%), yang memiliki status gizi lebih sebanyak 21 siswa (27.3\%) dan gizi kurang sebanyak 6 siswa $(7,8 \%)$. Berdasarkan data tersebut, hanya sebagian kecil siswa Sekolah Menengah Kejuruan yang berstatus gizi kurang.

Dari data tersebut didapatkan bahwa prestasi belajar siswa Sekolah Menengah Kejuruan Negeri 1 Polewali lebih banyak ditemukan siswa dengan prestasi belajar yang baik yaitu sebanyak 57 siswa (74.0\%) dan hanya sebagian kecil siswa yang memiliki prestasi yang kurang yaitu sebanyak 20 siswa $(25,9 \%)$. Nilai untuk siswa dengan prestasi belajar baik berada pada rentangan 80-89. Sedangkan untuk prestasi belajar kurang baik berada pada rentangan 70-79.

Ada hubungan antara status gizi dengan prestasi belajar siswa di Sekolah Menengah Kejuruan Negeri 1 Polewali Kecamatan Polewali Kabupaten Polewali Mandar.

\section{SARAN}

Bagi siswa yang berstatus gizi tidak baik sebaiknya lebih ditingkatkan lagi pengetahuan tentang status gizi dengan lebih banyak membaca dan belajar. Sedangkan siswa yang status 
Vol. 4, No. 2, Nopember 2018

p-ISSN: 2442-8884 / e-ISSN: 2541-4542

$\mathrm{J}$-Kesmas

Jurnal Kesehatan Masyarakat

gizinya tidak baik sebaiknya dilakukan

usaha seperti mengatur pola makan agar

statusgizinya menjadi baik sehingga

prestasi belajar dapat meningkat.

Diharapkan siswa menyadari

pentingnya mempunyai status gizi yang

baik yaitu tidak kurus dan tidak gemuk

agar siswa dapat menjalankan aktivitas

mereka dengan baik.

Bagi orang tua sebaiknya

memperhatikan status gizi, konsumsi makanan dan kecukupan asupan zat gizi putra-putrinya demi kelancaran belajarnya.

Bagi pihak sekolah sebaiknya dapat menjadikan hasil penelitian ini sebagai bahan kajian untuk memberikan wawasan tentang ilmu gizi mengingat masih ada sebagian siswa-siswi yang berstatus gizi tidak baik.

\section{DAFTAR PUSTAKA}

Olivia, Padriyani Steffi, Delmi Sulastri, Nur Afrainin Syah. 2013. Hubungan Status Gizi Dengan Prestasi Belajar Pada SiswaSiswi SMA 1 Negeri Padang. http://jurnal.fk.unand.ac.id/index . .php/jka/article oleh SO Padriyani 2014

Berita Kota Makassar. 25 April, 2010. Ironi Dunia Pendidikan 154 Siswa Tak Lulus UN,1. 